\title{
Understanding the Rappler Business Model: Implications for Sustainable Journalism
}

\author{
Luz Rimban ${ }^{1}$, Nurul Hasfi ${ }^{2}$, Sunarto $^{3}$, Amida Yusriana ${ }^{4}$ \\ $\left\{\right.$ lrimban@ateneo.edu $\left.{ }^{1}\right\}$ \\ Ateneo de Manila University, Philippines ${ }^{1}$ \\ Universitas Diponegoro, Indonesia ${ }^{2,3,4}$
}

\begin{abstract}
The news organization Rappler and the Philippine Center for Investigative Journalism have made significant contributions to journalism, not only in the Philippines but in Asia and around the world as well. They also represent innovative ways of truthtelling for which both organizations have experienced reprisals from officials they cover. PCIJ has survived for more than 30 years using a grant-driven business model that allows it to enjoy independence in its reportage. The objective of this paper is to analyze the Rappler business model. Rappler's business model is a combination of three: its daily operations mirror big, mainstream media driven by advertising; it is also an independent journalism organization partially subsisting through grants; and its digital innovation identifies it as a tech startup. Elements of the three models or revenue streams cancel each other out, as a result of which Rappler is still unable to prove its viability as a business entity. However, Rappler does raise the issue of the need for investors to help fund journalism enterprises in the country.
\end{abstract}

Keywords: Rappler, Maria Ressa, PCIJ, Sheila Coronel, Independent Journalism, Philippines, Press Freedom, Journalism Startup.

\section{Introduction}

When the New York-based Committee to Protect Journalists decided to confer the Gwen Ifill Press Freedom Award on Filipino journalist Maria Ressa in 2018, it chose another Filipino journalist to perform the task. That other journalist is Sheila Coronel, former executive director and founder of the Philippine Center for Investigative Journalism, a nonprofit news organization known for having done several groundbreaking reports, among which those that eventually helped lead to the downfall of then Philippine president Joseph Estrada in 2001. Coronel is now a professor at Columbia University in New York [1][2].

The significance of the two together could not have been lost on those who knew of their journalistic backgrounds. Almost 20 years since PCIJ uncovered Estrada's misdeeds, Rappler, headed by Ressa, is up against another president: Rodrigo Duterte. Ressa's name became associated with the struggle for press freedom because of what appears to be the Duterte government's reprisal against her and Rappler, the digital news organization she heads, over their coverage of his programs, specifically the extrajudicial killings of suspected drug pushers.

Coronel and Ressa have one other thing in common. Both are at the helm of two news organizations that changed the way news is gathered, written and delivered, although they came into existence more than 20 years apart under different media environments. PCIJ's 
content was originally geared mainly for print and eventually online publication, while Rappler is a digital-only news site.

PCIJ has remained in existence for 30 years, having been established in 1989 as an independent non-profit news organization that subsists on grants. It has been called "the gold standard for investigative reporting in Asia". Rappler was born in 2011, virtually a child still experiencing the growing pains of a young news organization [3]. The question this paper focuses on is: What is the Rappler business model and will it sustain the organization as PCIJ's business model sustained it for more than 30 years? What are the implications of the Rappler business model for independent journalism in the Philippines and Southeast Asia?

\section{Conceptual Framework}

The literature on journalism business models in the Philippines and Asia is sparse but abound elsewhere in the world. The term "business model" has been in academic literature since the 1940s, but became fashionable in the 1990s with the dot-com boom that brought with it the movement of tech companies pitching their companies to investors. A business model refers to the value that a company creates, and to the revenue sources that will enable it to carry out its mission for the long-term [4].

In the developed world, discussions and debates over the future of journalism in the midst of declining readership and audiences, and consequently, advertising revenues have prompted scholars to examine the business models and the business side of the profession, with some even saying that the news was never a commercially viable product, and that large newsrooms and usual revenue streams are no longer viable [5]. Scholars are also drawing attention to various efforts by journalists to face these challenges in the forms of new models: entrepreneurial initiatives, digital innovations and creative revenue streams [6][7][8][9][10].

Media considered critical of the current dispensation in their respective governments likewise engage in digital innovation and entrepreneurial creativity although under difficult circumstances. Clare E. Cook [11] studied 19 of them in nine countries where press freedom is threatened as "oppositional" or alternative media and classified by their sources of revenuegrant income, earned income and donations. Grant income comes in the form of funds given by donors; earned income comes in the forms of sales, subscriptions, advertising, and partnerships; donations constitute the support directly from the public in the form of crowdfunding, microdonations and non-monetary contributions.

Tech startups are often mentioned under business models but deserve specific mention. Startups are defined as small companies usually between one to five years old, characterized by a digital or online innovation and the potential to scale. Small entrepreneurs compete for funding from venture capitalists and other investors, including so-called "angel investors", using creative ideas that change the ways things are done or introduce a unique service or product [12].

In 2015, Columbia University conducted studies on media startups in the Global South and followed up on them two years later to see how they fared. The follow up study found that many of them were still dependent on donors but noted a trend toward professionalization in their business and financial management. Most were founded by four to 10 people, majority are able to pay their founders a salary, and the annual income funds operations for majority of the startups [13][14]. 
Based on the literature, this paper will use three main categories of news organizations to analyze the Rappler business model: traditional media, independent journalism organization and tech startup.

a) The traditional model refers to the big commercial organizations that are classified as mainstream and derive their income mostly from advertising or subscriptions.

b) The independent journalism organization refers to small, alternative media outlets that engage in niche reporting such as investigative journalism, and exist on grants that enable them to be independent of commercial and government influence.

c) The startup refers to the tech company model that is defined by online operations, digital innovation and the potential to scale.

\section{Research Method}

This study employed the method of document analysis. Primary documents used were the financial and organizational filings of Rappler with the Securities and Exchange Commission, the Philippines' corporate regulator. The SEC is the government agency that supervises the corporate sector, acts as registrar and overseer of some 600,000 corporations in the Philippines. It supervises for-profit or non-profit Corporations, partnerships and various forms of associations. The SEC is the repository of official information about Philippine corporations, their owners, financial standing and operations.

Types of primary documents obtained included its audited financial statements of Rappler, Inc. from its founding in 2011 to the latest filing in 2018. Other primary documents obtained from the SEC were the general information sheets that companies are required to submit.

Secondary documents used included articles written by and about Rappler by various entities since its founding. Finally, the study also looked the text and video versions of speeches delivered by Rappler founder Maria Ressa and articles written by her.

\section{Results and Discussion}

Rappler falls under the three business models of news organizations. An examination of its audited financial statements from 2011 to 2018, and an analysis of secondary documents show that Rappler has the elements of a startup, an independent journalism outfit and big media. It describes itself as "the Philippines' first all-digital news organization... combining technology and crowdsourcing through the use of social media and mobile phones to merge traditional television broadcasting with the Internet, reinventing systems and distribution channels" [15].

\subsection{Startup}

Rappler identifies as a startup, a tech-driven organization that delivers innovation and had the potential and plan to scale. Aside from the Philippines, Rappler has a news bureau in Indonesia. Its initial seed money came from its founders, most of it from Maria Ressa herself.

Foremost among its innovative tech features are its mood meter and mood navigator. The mood meter allows readers to select from a menu of icons the feelings that a particular story 
evokes while its mood navigator gives an overview of readers' reactions to its various articles. Rappler had its mood meter and mood navigator patented [16]. In its audited financial statements, it lists as part of its intangible assets it patented products [17].

As a startup, Rappler attracted so-called angel investors, a tech term that refers to wealthy individuals who offer capital to young companies. Pierre Omidyar of Omidyar Network and eBay could be considered one of Rappler's many investors, having poured in $\$ 1.5$ million into the company in its fourth year [18].

"As a startup company, Rappler is in the business of data and credible storytelling, services that we also extend to brand partners. Through the use of data, technology, and content, we help shape innovative and award-winning native advertising that aims to educate, empower, and inform the audience about latest trends and branded topics that are worth their time and attention", Rappler said in its article "The Story of Rappler" [19].

\subsection{Independent Journalism}

Rappler's mantra "the supremacy of editorial independence" embodies its identity an independent news outfit. It has produced highly acclaimed investigative reports and multimedia articles that examine government policies and draw attention to societal problems. It pursues investigative reporting through Newsbreak, an independent news organization formed in 2000 that eventually became the investigative and research arm of Rappler. It received its latest accolade in September 2019 when a seven-part Rappler investigation into extrajudicial killings under the government's campaign against drugs won the top prize in the prestigious Global Shining Light Award given out by the Global Investigative Journalism Network [20].

Evidence of its identity as an independent media organization is its sourcing of grants for projects which are often tied up with the particular advocacy of a donor. An example is it Agos-Bayanihan, a platform for climate change adaptation and disaster risk reduction developed with initial funding from the Australian government, Rappler said in its website. Government agencies are using the platform to be able to respond to emergencies. This is an example of how Rappler leverages its identity as a tech platform to offer a service that be a source of revenue [19].

\subsection{Traditional/big Media}

Rappler's operations mirror that of traditional or commercial media organizations, especially in terms of the size and scope of its operations. The Rappler website lists more than 70 staff, including nine desk persons, 14 multimedia reporters, 10 multimedia producers, 10 personnel for advertising and partnerships, and five social media producers. A typical Rappler page shows that it engages in a daily grind that churns out local and international news, apart from breaking news, sports, lifestyle, and entertainment [19].

Its contingent of staff dedicated to advertising and partnerships is evidence of the focus on revenue generation from advertisements and partnerships with various entities, at which Rappler has been able to generate hundreds of millions of pesos in revenues over the past seven-and-a-half years. BrandRap is the page within the Rappler website that contains Rappler's partnership with various business entities to produce their content and publish it on its website, to be seen by an audience of most young people. 
Rappler is all three rolled into one, and yet some elements of each one negates the other. For example, Rappler's enormous daily news operations and the huge salaries of its staff from its inception cancel out its identity as a startup which is supposed to be a small operation nurtured to grow as its business model proves viable.

Table 1. Rappler' s Annual Revenue

\begin{tabular}{|l|r|r|r|r|r|}
\hline \multicolumn{7}{|c|}{\begin{tabular}{l} 
Rappler, Inc. \\
(Based on audited financial statements from 2011 to 2018 \\
\hline
\end{tabular}} & $\begin{array}{l}\text { Salaries of key } \\
\text { management } \\
\text { personnel }\end{array}$ & Cost of services & \multicolumn{2}{l}{$\begin{array}{l}\text { General } \\
\text { operations } \\
\text { /admin }\end{array}$} & $\begin{array}{l}\text { TOTAL salaries, } \\
\text { cost of services, } \\
\text { etc }\end{array}$ & \multicolumn{1}{l|}{$\begin{array}{l}\text { Total Service } \\
\text { revenue }\end{array}$} \\
\hline 2011 & $960,000.00$ & $6,653,207.00$ & 0.00 & $6,653,207.00$ & \\
\hline 2012 & $4,200,000.00$ & $56,736,427.00$ & 0.00 & $56,736,427.00$ & $22,482,500.00$ \\
\hline 2013 & $12,400,000.00$ & $98,196,854.00$ & $29,181,685.00$ & $127,378,539.00$ & $57,550,754.00$ \\
\hline 2014 & $12,400,000.00$ & $114,322,654.00$ & $34,083,461.00$ & $148,406,115.00$ & $116,062,189.00$ \\
\hline 2015 & $12,400,000.00$ & $133,433,496.00$ & $46,302,985.00$ & $179,736,481.00$ & $139,461,654.00$ \\
\hline 2016 & $23,300,000.00$ & $129,391,540.00$ & $52,802,561.00$ & $182,194,101.00$ & $173,825,669.00$ \\
\hline 2017 & $22,467,150.00$ & $132,786,532.00$ & $67,968,990.00$ & $200,755,522.00$ & $138,143,057.00$ \\
\hline 2018 & $19,999,728.00$ & $103,679,807.00$ & $70,956,382.00$ & $174,636,189.00$ & $134,648,155.00$ \\
\hline Total & & & & $1,076,496,581.00$ & $\mathbf{7 8 2 , 1 7 3 , 9 7 8 . 0 0}$ \\
\hline
\end{tabular}

Source: Rappler Inc.

The table 1 shows the scale of Rappler's operations, through the salaries paid to key management personnel, the cost of services and general operations as well as its revenue. The figures are in Philippine pesos and are based on the financial statements from 2011 to 2018.

Through its daily reportage, Rappler competes with the traditional big media for stories. The daily reportage hardly offers anything new or deep to make it stand out from competitors, but its value comes in putting the organization out as a news presence in the various beats which include the presidency, Congress, the military and the police.

The big operation also goes against the grain of independent news outfits that focus on specific niches in their reportage. A niche allows the organization to specialize and eventually gain expertise on a specific service or skill. For now, Rappler's reporting niche is still unclear, and there is no one type of consistent reportage or area of expertise that can be said to be its brand. What is clear in the past few years is that Rappler's brand has been its feisty founder, Maria Ressa, and individual reporters such as Pia Rañada who is known for having covered Duterte and incurring his ire for stories she had produced. Rañada has been excluded from presidential coverage, an issue that has prompted Rappler to assert journalists' right to information and coverage before the Supreme Court.

Rapplers' financial statements show that its revenues could not cover the cost of daily news operations, as a result of which Rappler had to welcome investors. In 2015, according to its financial statement for that year, Rappler Board of Directors approved the increase in authorized capital stock from 3 million shares to 446 million shares with a par value of P1. It also approved the issuance of more than 110 million common shares to its parent Rappler Holdings [21]. By November that year, Rappler announced the investment of Omidyar Network through Philippine Depository Receipts (PDR) of some \$1.5 million [15]. 
The infusion of such a huge amount into a small and medium entity showed up on the radar of the Securities and Exchange Commission, the Philippines' corporate regulator. After several months of inquiries into Rappler's PDRs, the SEC in January 2018 ordered the revocation of Rappler's license for violation of the constitutional provision against foreign ownership of media entities [17].

Rappler and the journalistic community viewed the order to revoke its license as an attack against press freedom, coming as it did in the heels of government pronouncements against two other news organizations considered critical of Duterte. Duterte has threatened broadcast conglomerate ABS-CBN with the non-renewal of its congressional franchise and accused the country's top broadsheet the Philippine Daily Inquirer of tax evasion and unscrupulous business practices.

The SEC revocation order was quickly followed by a slew of other cases against Ressa, the company and its parent, Rappler Holdings Inc. As of July 2019, Rappler, its managers, editors and a reporter were facing a total of 11 administrative proceedings and complaints. They have had to post bail amounting to P2 million [22].

In 2018, Rappler decided to appeal the SEC's revocation of its corporate registration before the Court of Appeals. Omidyar meanwhile donated his PDRs to members of Rappler's management. Rappler argued before the Appellate Court that Omidyar's donation of his PDRs to Rappler officers removes questions over foreign ownership. The Court however decided to toss the case back to the SEC, since Rappler failed to submit documents pertaining to the donation, including the conditions or terms of the Omidyar donation [17].

\section{Conclusion}

Rappler's business model can be said to have been the cause of its problems against the government, whether or not government action against it is viewed as a deliberate attack on press freedom. Ressa herself, in a speech before the Committee to Project Journalists in 2018, said, "I'm being attacked not just as a journalist but as the founder of a company that successfully and legally raised money to make an idea a reality".

Whether the fund generation was legal is something the government is contesting, arguing the ban on foreign ownership in Philippine media companies. The ban is, indeed, a hindrance to the growth of journalism startups in the Philippines and the Rappler case is a signal for investors to stay away from such startups. It should be noted that the Philippines enjoys a lively and flourishing startup environment on businesses outside the realm of the media, and the constitutional ban shuts journalism out of much needed sources of seed capital.

"Let my government know that you do not agree with its draconian measures and the signal it sends to investors - that the Philippines is not ready for innovation or investment", Ressa added in her speech to the CPJ in 2018.

The cases filed against Rappler are also causing a financial drain on the company. As to its current financial position, it said in its latest financial statement that it has "identified possible measures to improve its performance and financial position which include a new business model, a new technology platform, and addressing cost efficiency by trimming down corporate expenses". 
Philippine journalism experience and literature on journalism startups and independent media in Asia and elsewhere have shown that a news organization does not have to scale to make an impact, to build a steady audience, and to produce well-researched and well-written reports. Following the experience of PCIJ, what matters is that a news organization's identity and business model are clear and its mission focused. There are tradeoffs, as in any business. For instance, a small nonprofit independent news organization may enjoy such privileges as tax exemptions but faces the constant pressure to search for grants to survive and to be able to maintain an organization that will fulfill its obligations to projects and donors.

Concerns over the survival of journalism as a profession and or journalism entities as business models have not yet taken root in the Philippines, where the discussions often center on the personal physical survival of individual journalists in the face of restrictions on press freedom.

\section{References}

[1] Committee to Protect Journalists, Maria Ressa: 2018 Gwen Ifill Press Freedom Award. 2018.

[2] Rappler, Sheila Coronel introduces Maria Ressa at the CPJ 2018 Awards. 2018.

[3] D. E. Kaplan, "Global Investigative Journalism," Strateg. Support. A Rep. to Cent. Int. Media Assist., 2013.

[4] M. Peric, J. Durkin, and V. Vitezic, "The constructs of a business model redefined: A halfcentury journey," Sage Open, vol. 7, no. 3, p. $2158244017733516,2017$.

[5] R. G. Picard, "A business perspective on challenges facing journalism," Chang. Bus. Journal. its Implic. Democr., pp. 17-24, 2010.

[6] D. Wilding, P. Fray, S. Molitorisz, and E. McKewon, "The Impact of Digital Platforms on News and Journalistic Content." University of Technology Sydney. Retrieved from https://www. uts. edu. au ..., 2018.

[7] A. K. Bittner, "Digital Journalism and New Business Models," 2019.

[8] Z. Ismail, "Strengthening the Financial Independence of Independent Media Organisations," 2018.

[9] S. Wunsch-Vincent, G. Vickery, C. S. Vallejo, and S. Y. Oh, "The evolution of news and the Internet," Organ. Econ. Co-operation Dev. Work. Party Inf. Econ. (Report No. DSTI/ICCP/IE 14/FINAL), http//www. oecd. org/officialdocuments/displaydocumentpdf, 2010.

[10] D. Levy and R. K. Nielsen, The changing business of journalism and its implications for democracy. Reuters Institute for the Study of Journalism, 2010.

[11] C. E. Cook, "Fragile finance: The revenue models of oppositional news outlets in repressive regimes," Int. Commun. Gaz., vol. 78, no. 6, pp. 514-535, 2016.

[12] L. Steigertahl, R. Mauer, and J. B. Say, "EU Start-up Monitor.” European Commission: ESCP Europe Jean-Baptiste Say Institute for ..., 2018.

[13] J. J. Robinson, K. Grennan, and A. Schiffrin, "Publishing for peanuts," Innov. Journal. startup, 2015.

[14] A. Schiffrin, "Fighting for survival: Media startups in the Global South," Cent. Int. Media Assist., 2019.

[15] Rappler.com, "Omidyar Network invests in Rappler," November 5, 2015. [Online]. Available: https://www.rappler.com/about-rappler/about-us/109992-omidyar-network-invests-rappler.

[16] Rappler.com, “The Rappler Story: Independent Journalism with Impact,” October 19, 2017.

[17] Rappler Inc, "2018 Financial Statement," May 7, 2019. .

[18] CNN Philippines Staff, "Omidyar Network donates investment to Rappler's Filipino managers," March 1, 2018. [Online]. Available: https://cnnphilippines.com/news/2018/02/28/OmidyarNetwork-donates-investment-to-Rapplers-Filipino-managers.html.

[19] Rappler.com, “\#ThewRap: Things you need to know," October 19, 2017. [Online]. Available: 
https://www.rappler.com/the-wrap/185759-daily-news-highlights-october-19-2017-edition.

[20] J. Gavilan, "Rappler investigation into war on drugs wins 2019 Global Shining Light Award," September 29, 2019. [Online]. Available: https://www.rappler.com/about-rappler/aboutus/241314-rappler-investigation-into-war-on-drugs-wins-2019-global-shining-light-award.

[21] Rappler Inc, “2015 Financial Statement,” May 4, 2016.

[22] Rappler.com., "Maria Ressa posts P126,000 bail for new case," April 1, 2019. . 